\title{
Flow-by-flow chemical stratigraphy and evolution of thirteen Serra Geral Group basalt flows from Vista Alegre, southernmost Brazil
}

\author{
VITER M. PINTO ${ }^{1}$ and LÉO A. HARTMANN ${ }^{2}$ \\ ${ }^{1}$ Instituto de Geociências, Universidade Federal de Roraima, Campus Paricarana, \\ Av. Capitão Ene Garcez, 2413, 69304-000, Boa Vista, RR, Brasil \\ ${ }^{2}$ Instituto de Geociências, Universidade Federal do Rio Grande do Sul, \\ Av. Bento Gonçalves, 9500, 91501-970 Porto Alegre, RS, Brasil \\ Manuscript received on October 9, 2009; accepted for publication on October 27, 2010
}

\begin{abstract}
The geochemical characterization of thirteen Serra Geral Group flows in the Vista Alegre region (RS-SC), southern Brazil, displays the homogeneous basaltic composition near $50 \mathrm{wt} . \% \mathrm{SiO}_{2}$. Each of the five basal flows (Pitanga-type, high-Ti/Y $\sim 600, \mathrm{TiO}_{2}>3$ wt.\%) and eight upper flows (Paranapanema-type, medium $\mathrm{Ti} / \mathrm{Y} \sim 400, \mathrm{TiO}_{2}>2$ wt.\%) can be identified from their chemical composition; sets of flows have parallel variation in chemical composition. The flow-by-flow correlation in four sections shows the horizontal position of the flows in three profiles and an approximately 200-m downdrop of the Itapiranga block with respect to the Frederico Westphalen block. The world-class amethyst geode mineralization and the systematic presence of native copper in the basalts make the correlation of great geological and economic significance.
\end{abstract}

Key words: Geochemical correlation, basalt, stratigraphy, Serra Geral Group, Vista Alegre.

\section{INTRODUCTION}

The Paraná volcanic province is one of the largest continental flood basalt associations in the world. The province is of major significance for the understanding of many aspects of mantle evolution, and its large extent requires careful examination of the lava flow stratigraphy to evaluate the metallogenic potential for amethyst geodes and copper. The Vista Alegre copper district is at the center of this investigation and has many occurrences of this metal, and the Ametista do Sul mining district nearby is the largest world producer of amethyst geodes (400 tons/month). The two districts straddle the border of the southernmost states of Santa Catarina and Rio Grande do Sul in Brazil. In order to clarify the geological relationships in the Serra Geral Group (Wildner et al. in press) of this region, and particularly the flowby-flow stratigraphy, we conducted an integrated field

Correspondence to: Léo Afraneo Hartmann

E-mail: leo.hartmann@ufrgs.br and geochemical investigation of the basalts in four different sections. We also tested the presence of the often purported Rio Uruguay fault and its impact on flow stratigraphy.

\section{GEOLOGICAL BACKGROUND}

The Serra Geral Group includes all Paraná volcanic province lava flows (Wildner et al. in press). This large igneous province covers an extensive area in southeastern South America, with minor Etendeka remnants in Namibia on the African plate, originally a single magmatic province (Bellieni et al. 1984). This mantle-derived magmatism was closely associated with the opening of the South Atlantic Ocean under the thermal influence of the Tristan plume in the Lower Cretaceous (Peate et al. 1992, Turner et al. 1999).

The lava pile of Paraná-Etendeka magmatism is strongly bimodal, dominated by tholeiitic basalts (>90\%), but significant quantities of rhyodacites are 
found along the Brazilian continental margin and in the Etendeka (Peate 1997). Our usage of rhyodacite includes several other siliceous volcanic rocks, such as quartz-latites and dacites.

Six magma types were identified by Peate et al. (1992) from geochemistry of surface and borehole samples, distributed between low-Ti (Gramado, Esmeralda, Ribeira) and high-Ti (Urubici, Pitanga, Paranapanema) types. They proposed that both low-Ti and high-Ti varieties have a plume-related origin, with an extensive crustal contamination in the low-Ti basalts.

Chemical stratigraphy has an important role in the understanding of large igneous provinces, e.g. Columbia River (Swanson et al. 1979), Deccan (Cox and Hawkesworth 1985, Beane et al. 1986) and Emeishan (Xu et al. 2001), particularly of magmatic sources and evolutionary processes (Peate et al. 1992). In the Paraná volcanic province (usage as in Hartmann et al. 2010), Turner et al. (1999) studied basaltic and rhyolitic lavas in drill holes from western Uruguay showing a reverse magma-type stratigraphy in which magma types are not chronostratigraphic. On the other hand, Peate et al. (1999) recognized 19 flows (Urubici type) in the São Joaquim area and suggested that lavas near the coast underwent $1 \mathrm{~km}$ post-magmatic uplift relative to inland areas. Each of these 19 flows has a characteristic chemical composition.

The Vista Alegre region has high-Ti magma types: Pitanga at the base and Paranapanema at the top, in the general sequence recognized by Mantovani et al. (1988) in outcrops and boreholes. These two magma types have a close spatial association, comprising approximately $\sim 50 \%$ of the total preserved lava field in the Paraná province. The two types are distinguished (Peate et al. 1992) only from the content of incompatible elements (e.g. Ti/Y $\sim 410$ and $\mathrm{TiO}_{2} \sim 2.5$ wt. $\%$ in Paranapanema type, $\sim 530$ and $3.5 \mathrm{wt} . \%$ in Pitanga type). They have a restricted range in $\mathrm{Sr}, \mathrm{Nd}$ and $\mathrm{Pb}$ isotopic composition $\left({ }^{87} \mathrm{Sr} /{ }^{86} \mathrm{Sr}_{\mathrm{i}}=0.7055-0.7063 ; \varepsilon \mathrm{Nd}_{\mathrm{i}}=-1.6\right.$ to -3.6 ; $\left.{ }^{206} \mathrm{~Pb} /{ }^{204} \mathrm{~Pb}=17.81-18.12\right)$ and were grouped together with Ribeira magma type as the "Northern" basalts by Peate (1997).

\section{METHODOLOGY AND SAMPLING}

The massive central portion of basalt flows is chemically homogeneous both in horizontal and vertical sec- tions, so we collected one rock sample from the core of every flow present in four sections of the Vista Alegre region to establish the flow-by-flow stratigraphy. An additional flow (possibly two, not investigated) may be present in the Rio Uruguay bed.

The studied region (Fig. 1) covers $\sim 2,000 \mathrm{~km}^{2}$ and has a total lava section of $\sim 1,200 \mathrm{~m}$ in Vista Alegre, as observed in a drill hole by the Geological Survey of Brazil for water in the nearby Iraí. Thus, the Botucatu Formation sandstones are buried by $800-1100 \mathrm{~m}$ of basalts and rhyodacites in the region. The top of the hills are near $600 \mathrm{~m}$ high and the Rio Uruguay valley is at $250 \mathrm{~m}$; the entire region was covered by the Atlantic forest, but now has mostly crops.

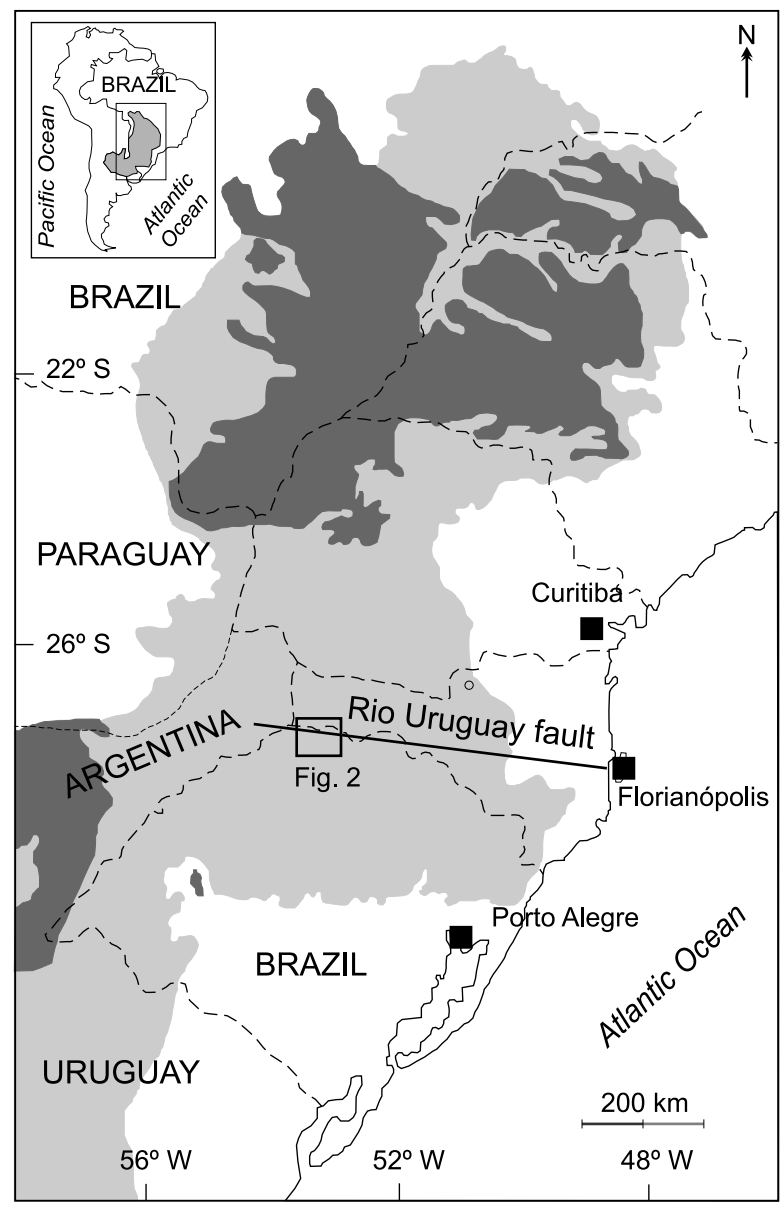

Fig. 1 - Geologic map of southeastern South America, showing the Serra Geral Group basalts and rhyodacites (light gray) in the Paraná basin, the underlying sedimentary rocks, Precambrian basement (white), sedimentary cover rocks (dark gray), modified from Peate et al. (1992). Studied Vista Alegre region indicated. 


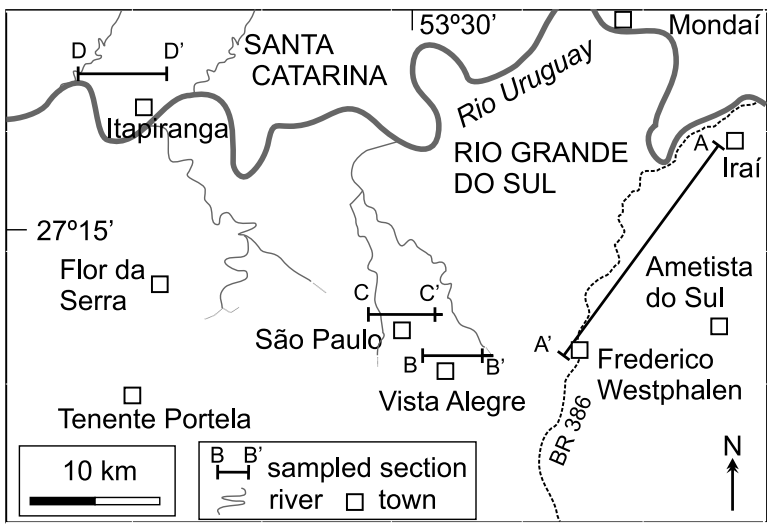

Fig. 2 - Location map of the Vista Alegre region. Four studied sections indicated.

The Vista Alegre region basalts (Fig. 2) were studied by Szubert et al. (1979), who recognized the presence of thirteen basalt flows in the region, later studied by Gomes (1996). Our field work in 2006-2007 led to the understanding of geological relationships and the collection of samples for petrography and chemical analyses. Backscattered electron (BSE) images were obtained with an electron microprobe (EPMA) using a JEOL JSM-6400 (WDS/EDS) at the University of Western Australia, operated at $15 \mathrm{kV}$ accelerating potential and $15 \mathrm{nA}$ beam current. Chemical analyses (Table I) of bulk rocks were performed by ACME Analytical Laboratories, Vancouver, Canada. Major elements were determined by X-ray fluorescence spectrometry and trace elements, metals and REE by inductively coupled plasma mass spectrometry (ICP-MS). Total Fe is indicated as $\mathrm{Fe}_{2} \mathrm{O}_{3}$.

The four selected sections (Fig. 3) are Iraí-Frederico Westphalen (IF), Itapiranga (It), Vista Alegre (VA) and São Paulo (SP). The thirteen flows identified are nearly horizontal, as seen on aerial photos and in the field.

\section{FLOW CHARACTERISTICS}

The morphological and structural characteristics, in the Vista Alegre region typically comprise inflated pahoehoe sheets associated with massive flows $10-70 \mathrm{~m}$ thick. A single flow can display variable internal structure, thickness, morphology and petrographic textures over a few kilometers because of lateral variations in the local cooling conditions, paleotopography, and distance from the vent source (Peate et al. 1999). Lava flows in the Vista Alegre region have two main structural types (Gomes 1996): a) type I, with thickness between 15-30 m, thin amygdaloidal upper and lower crusts and a massive internal portion that may contain giant amethyst-bearing geodes; b) type II, thickness 30-70 m, thick upper and thin lower amygdaloidal crusts and an internal portion characterized by collonnade and entablature vertical joints. Each flow is often separated from another by a thin layer $(<50 \mathrm{~cm})$ of silicified sandstone that indicates the persistence of the arid desert climate that typifies the sedimentary rocks of the underlying Botucatu Formation (Peate et al. 1999). Flow contacts are also marked by the presence of hydrothermal breccias at the top of the underlying flow.

Most basalts are subaphyric, but a few have porphyritic or glomeroporphyritic portions with plagioclase and minor clinopyroxene phenocrysts (flows 1, 4, 5 and 11). Samples of the flows have similar mineralogy, with labradorite (55-70 vol.\%), augite-pigeonite (25-35\%) and Ti-magnetite + ilmenite (5-10\%), plus rare, highly altered olivine; apatite is the principal accessory mineral. Interstitial material in the groundmass consists of variable proportions of plagioclase, clinopyroxene, quartz, K-feldspar and Ti-Fe oxides. It is significant that the Pitanga basalts have higher modal contents of altered olivine and needle-like grains of ilmenite coexisting with Ti-magnetite (Fig. 4a). In the Paranapanema-type flows 6 to 13, ilmenite occurs preferentially as oriented exsolution lamellae in magnetite grains (Fig. 4b). Ilmenite shows trellis or sandwich texture in both Pitanga and Paranapanema magma types. This is a consequence of the higher $\mathrm{TiO}_{2}$ content $(\sim 3.5 \%)$ and possibly lower oxygen fugacity of the bottom five Pitanga flows compared to the upper Paranapanema flows $\left(\sim 2.5 \% \mathrm{TiO}_{2}\right)$.

\section{GEOCHEMICAL RESULTS}

All thirteen flows plot in the tholeiitic basalt field on the total alkalis-silica (TAS) diagram with approximately 50 wt. $\% \mathrm{SiO}_{2}$ (Fig. 5). Flows 1 to 5 have Ti/Y ratios $\sim 600$, while the upper 6-13 flows have $\mathrm{Ti} / \mathrm{Y} \sim 400$. 
TABLE I

Major (wt.\%), minor (wt.\%) and trace (ppm) elements of basalts from the Vista Alegre region.

\begin{tabular}{|c|c|c|c|c|c|c|}
\hline Samples & VIF12 & VIF11 & VIF 10 & VIF09 & VIF08 & VIF07 \\
\hline Northing $^{\mathrm{a}}$ & 0263100 & 0264817 & 0264270 & 0264720 & 0265750 & 0267347 \\
\hline Easting $^{\mathrm{a}}$ & 6969500 & 6971960 & 6974033 & 6977212 & 6978030 & 6979713 \\
\hline \multirow{2}{*}{ Elevation (m) } & 540 & 480 & 460 & 425 & 410 & 390 \\
\hline & \multicolumn{6}{|c|}{ Section Iraí-Frederico } \\
\hline \multicolumn{7}{|c|}{ Major oxides (wt.\%) } \\
\hline $\mathrm{SiO}_{2}$ & 50.17 & 50.54 & 50.12 & 49.86 & 50.53 & 50.4 \\
\hline $\mathrm{TiO}_{2}$ & 2.44 & 2.45 & 2.55 & 2.46 & 2.45 & 2.41 \\
\hline $\mathrm{Al}_{2} \mathrm{O}_{3}$ & 12.77 & 12.66 & 12.82 & 12.42 & 12.53 & 12.52 \\
\hline $\mathrm{Fe}_{2} \mathrm{O}_{3}(\mathrm{t})$ & 15.61 & 16.02 & 16.14 & 15.5 & 15.82 & 14.91 \\
\hline $\mathrm{MgO}$ & 4.8 & 4.89 & 4.6 & 4.84 & 4.74 & 5.1 \\
\hline $\mathrm{CaO}$ & 8.6 & 8.7 & 8.5 & 8.4 & 8.8 & 8.59 \\
\hline $\mathrm{Na}_{2} \mathrm{O}$ & 2.43 & 2.47 & 2.66 & 2.39 & 2.44 & 2.45 \\
\hline $\mathrm{K}_{2} \mathrm{O}$ & 1.26 & 1.29 & 1.27 & 1.59 & 1.22 & 1.36 \\
\hline $\mathrm{P}_{2} \mathrm{O}_{5}$ & 0.27 & 0.26 & 0.28 & 0.27 & 0.27 & 0.27 \\
\hline $\mathrm{MnO}$ & 0.2 & 0.23 & 0.19 & 0.21 & 0.22 & 0.22 \\
\hline $\mathrm{Cr}_{2} \mathrm{O}_{3}$ & 0.01 & 0.01 & 0.01 & 0.01 & 0.01 & 0.01 \\
\hline LOI & 1.2 & 0.4 & 1 & 2 & 0.9 & 1.7 \\
\hline Total & 99.96 & 99.93 & 99.96 & 99.96 & 99.95 & 99.95 \\
\hline \multicolumn{7}{|c|}{ Trace elements (ppm) } \\
\hline $\mathrm{Cu}$ & 185.3 & 324.4 & 115.4 & 150 & 385 & 265.1 \\
\hline $\mathrm{Ni}$ & 36 & 33 & 38 & 37 & 39 & 39 \\
\hline $\mathrm{Ba}$ & 328 & 302.1 & 312.8 & 321.2 & 307.4 & 289.1 \\
\hline $\mathrm{Be}$ & 1 & 1 & 1 & 1 & 1 & 1 \\
\hline $\mathrm{Co}$ & 44.6 & 44.8 & 40.6 & 41.5 & 42.8 & 44.8 \\
\hline $\mathrm{Cs}$ & 0.5 & 0.4 & 0.1 & 0.5 & 0.2 & 0.2 \\
\hline $\mathrm{Ga}$ & 19.5 & 18.8 & 19.7 & 18.9 & 19 & 18.7 \\
\hline Hf & 4.8 & 5 & 4.6 & 4.6 & 4.4 & 4.4 \\
\hline $\mathrm{Nb}$ & 14.8 & 15.1 & 15.1 & 14.5 & 14.6 & 14.5 \\
\hline $\mathrm{Rb}$ & 32.8 & 29.4 & 18.5 & 47 & 24.9 & 30.3 \\
\hline $\mathrm{Sn}$ & 1 & 1 & 1 & 1 & 1 & 2 \\
\hline $\mathrm{Sr}$ & 263.5 & 271.1 & 259.6 & 258.6 & 269.6 & 256.6 \\
\hline $\mathrm{Ta}$ & 0.9 & 0.8 & 0.8 & 0.8 & 0.8 & 0.8 \\
\hline $\mathrm{Th}$ & 2.3 & 2.2 & 2.3 & 2.1 & 1.9 & 2.7 \\
\hline $\mathrm{U}$ & 0.4 & 0.5 & 0.5 & 0.5 & 0.5 & 0.5 \\
\hline $\mathrm{V}$ & 456 & 467 & 478 & 459 & 451 & 455 \\
\hline W & 0.3 & 0.2 & 1 & 0.3 & 0.4 & 0.4 \\
\hline $\mathrm{Zr}$ & 173.1 & 169.8 & 169.3 & 165.1 & 167.1 & 162.4 \\
\hline $\mathrm{Y}$ & 45.4 & 37.7 & 36.2 & 36.4 & 37.5 & 35.6 \\
\hline $\mathrm{La}$ & 24 & 20.3 & 20.6 & 20.4 & 20.8 & 20 \\
\hline $\mathrm{Ce}$ & 47.3 & 45.7 & 45.1 & 44.9 & 45.5 & 44.1 \\
\hline $\operatorname{Pr}$ & 6.76 & 6.14 & 5.97 & 5.88 & 6.04 & 5.82 \\
\hline $\mathrm{Nd}$ & 29.7 & 26.2 & 25.9 & 25.2 & 26.9 & 24.9 \\
\hline $\mathrm{Sm}$ & 6.5 & 6.02 & 5.99 & 5.76 & 6.08 & 5.78 \\
\hline $\mathrm{Eu}$ & 2.08 & 1.75 & 1.76 & 1.73 & 1.8 & 1.75 \\
\hline $\mathrm{Gd}$ & 7.38 & 6.53 & 6.25 & 6.35 & 6.43 & 6.13 \\
\hline $\mathrm{Tb}$ & 1.35 & 1.23 & 1.18 & 1.12 & 1.16 & 1.11 \\
\hline Dy & 8.23 & 7.11 & 6.88 & 6.34 & 7.01 & 6.34 \\
\hline Ho & 1.55 & 1.27 & 1.23 & 1.23 & 1.25 & 1.23 \\
\hline $\mathrm{Er}$ & 4.88 & 3.79 & 3.81 & 3.83 & 3.73 & 3.73 \\
\hline $\mathrm{Tm}$ & 0.78 & 0.61 & 0.57 & 0.61 & 0.59 & 0.57 \\
\hline $\mathrm{Yb}$ & 4.35 & 3.66 & 3.44 & 3.49 & 3.55 & 3.36 \\
\hline $\mathrm{Lu}$ & 0.76 & 0.57 & 0.57 & 0.56 & 0.55 & 0.51 \\
\hline
\end{tabular}


TABLE I (continuation)

\begin{tabular}{|c|c|c|c|c|c|c|}
\hline Samples & VIF06 & VIF05 & VIF04 & VIF03 & VIF02 & VIF01 \\
\hline Northing $^{\mathrm{a}}$ & 0267855 & 0268174 & 0268563 & 0273553 & 0274602 & 0276930 \\
\hline Easting $^{\mathrm{a}}$ & 6981646 & 6984390 & 6984670 & 6989620 & 6990150 & 6991150 \\
\hline \multirow{2}{*}{ Elevation (m) } & 360 & 320 & 290 & 260 & 240 & 210 \\
\hline & \multicolumn{6}{|c|}{ Section Iraí-Frederico West } \\
\hline \multicolumn{7}{|c|}{ Major oxides (wt.\%) } \\
\hline $\mathrm{SiO}_{2}$ & 49.31 & 49.06 & 47.23 & 49.47 & 49.02 & 49.75 \\
\hline $\mathrm{TiO}_{2}$ & 2.42 & 3.69 & 3.88 & 3.35 & 3.78 & 3.95 \\
\hline $\mathrm{Al}_{2} \mathrm{O}_{3}$ & 13.00 & 12.36 & 12.59 & 12.46 & 12.51 & 12.78 \\
\hline $\mathrm{Fe}_{2} \mathrm{O}_{3}(\mathrm{t})$ & 14.92 & 15.81 & 15.98 & 15.25 & 15.39 & 14.78 \\
\hline $\mathrm{MgO}$ & 5.64 & 4.33 & 4.53 & 4.14 & 3.96 & 4.34 \\
\hline $\mathrm{CaO}$ & 9.82 & 8.36 & 8.68 & 8.33 & 8.3 & 8.19 \\
\hline $\mathrm{Na}_{2} \mathrm{O}$ & 2.25 & 2.47 & 2.42 & 2.76 & 2.51 & 2.59 \\
\hline $\mathrm{K}_{2} \mathrm{O}$ & 0.77 & 1.48 & 1.17 & 0.88 & 1.59 & 1.56 \\
\hline $\mathrm{P}_{2} \mathrm{O}_{5}$ & 0.27 & 0.53 & 0.59 & 0.47 & 0.6 & 0.48 \\
\hline $\mathrm{MnO}$ & 0.2 & 0.22 & 0.21 & 0.21 & 0.21 & 0.19 \\
\hline $\mathrm{Cr}_{2} \mathrm{O}_{3}$ & 0.02 & 0 & 0.01 & 0.01 & 0 & 0 \\
\hline LOI & 1.6 & 1.6 & 2.6 & 2.4 & 1.9 & 1.3 \\
\hline Total & 99.93 & 99.92 & 99.89 & 99.73 & 99.78 & 99.93 \\
\hline \multicolumn{7}{|c|}{ Trace elements (ppm) } \\
\hline $\mathrm{Cu}$ & 229.4 & 112.2 & 172.4 & 231.6 & 174.5 & 36.8 \\
\hline $\mathrm{Ni}$ & 50 & 21 & 19 & 34 & 23 & 61 \\
\hline $\mathrm{Ba}$ & 340.8 & 438.6 & 510.4 & 497.9 & 484 & 431.1 \\
\hline $\mathrm{Be}$ & 1 & 1 & 1 & 1 & 1 & 1 \\
\hline Co & 45.8 & 42.7 & 38.9 & 38.3 & 39.9 & 40.6 \\
\hline Cs & 0.1 & 0.3 & 0.4 & 0.4 & 0.3 & 0.3 \\
\hline $\mathrm{Ga}$ & 19.2 & 21.5 & 21.8 & 21.6 & 21.4 & 23.2 \\
\hline $\mathrm{Hf}$ & 3.9 & 6.1 & 6.8 & 6.5 & 6.5 & 7.3 \\
\hline $\mathrm{Nb}$ & 14 & 24.6 & 27.3 & 26 & 26.6 & 23.8 \\
\hline $\mathrm{Rb}$ & 10.9 & 30.5 & 16.4 & 25.8 & 31.5 & 29.6 \\
\hline $\mathrm{Sn}$ & 1 & 2 & 2 & 2 & 2 & 2 \\
\hline $\mathrm{Sr}$ & 364.2 & 417.1 & 466.6 & 444.1 & 428.2 & 516 \\
\hline $\mathrm{Ta}$ & 0.7 & 1.4 & 1.6 & 1.5 & 1.5 & 1.4 \\
\hline Th & 2.4 & 3.8 & 4.5 & 3.9 & 3.6 & 2.8 \\
\hline $\mathrm{U}$ & 0.5 & 0.8 & 0.8 & 0.7 & 0.8 & 0.7 \\
\hline V & 494 & 511 & 454 & 434 & 437 & 455 \\
\hline W & 0.2 & 0.3 & 1.1 & 0.4 & 0.3 & 0.5 \\
\hline $\mathrm{Zr}$ & 140.5 & 227.1 & 248.7 & 249.9 & 243.4 & 267.7 \\
\hline $\mathrm{Y}$ & 29.2 & 38.2 & 39.7 & 38 & 40.2 & 36.9 \\
\hline $\mathrm{La}$ & 19.5 & 31.4 & 34.5 & 34.1 & 35.9 & 32.5 \\
\hline $\mathrm{Ce}$ & 44 & 69.1 & 76.2 & 73.8 & 76 & 71.5 \\
\hline $\operatorname{Pr}$ & 5.76 & 9.26 & 10.28 & 9.76 & 10.23 & 9.99 \\
\hline $\mathrm{Nd}$ & 25.2 & 39.2 & 44.2 & 40.7 & 43.9 & 43.5 \\
\hline $\mathrm{Sm}$ & 5.39 & 8.21 & 9.14 & 8.65 & 8.9 & 9.42 \\
\hline $\mathrm{Eu}$ & 1.71 & 2.45 & 2.75 & 2.54 & 2.67 & 2.93 \\
\hline $\mathrm{Gd}$ & 5.6 & 8.02 & 8.78 & 8.15 & 8.6 & 8.79 \\
\hline $\mathrm{Tb}$ & 0.99 & 1.51 & 1.46 & 1.38 & 1.46 & 1.48 \\
\hline Dy & 5.57 & 7.36 & 7.84 & 7.64 & 8.03 & 7.78 \\
\hline Но & 1.05 & 1.3 & 1.38 & 1.32 & 1.41 & 1.33 \\
\hline $\mathrm{Er}$ & 3.04 & 3.66 & 3.93 & 3.76 & 4.07 & 3.58 \\
\hline $\mathrm{Tm}$ & 0.49 & 0.56 & 0.56 & 0.57 & 0.61 & 0.53 \\
\hline $\mathrm{Yb}$ & 2.72 & 3.39 & 3.46 & 3.42 & 3.41 & 3.01 \\
\hline $\mathrm{Lu}$ & 0.44 & 0.5 & 0.51 & 0.5 & 0.51 & 0.46 \\
\hline
\end{tabular}


TABLE I (continuation)

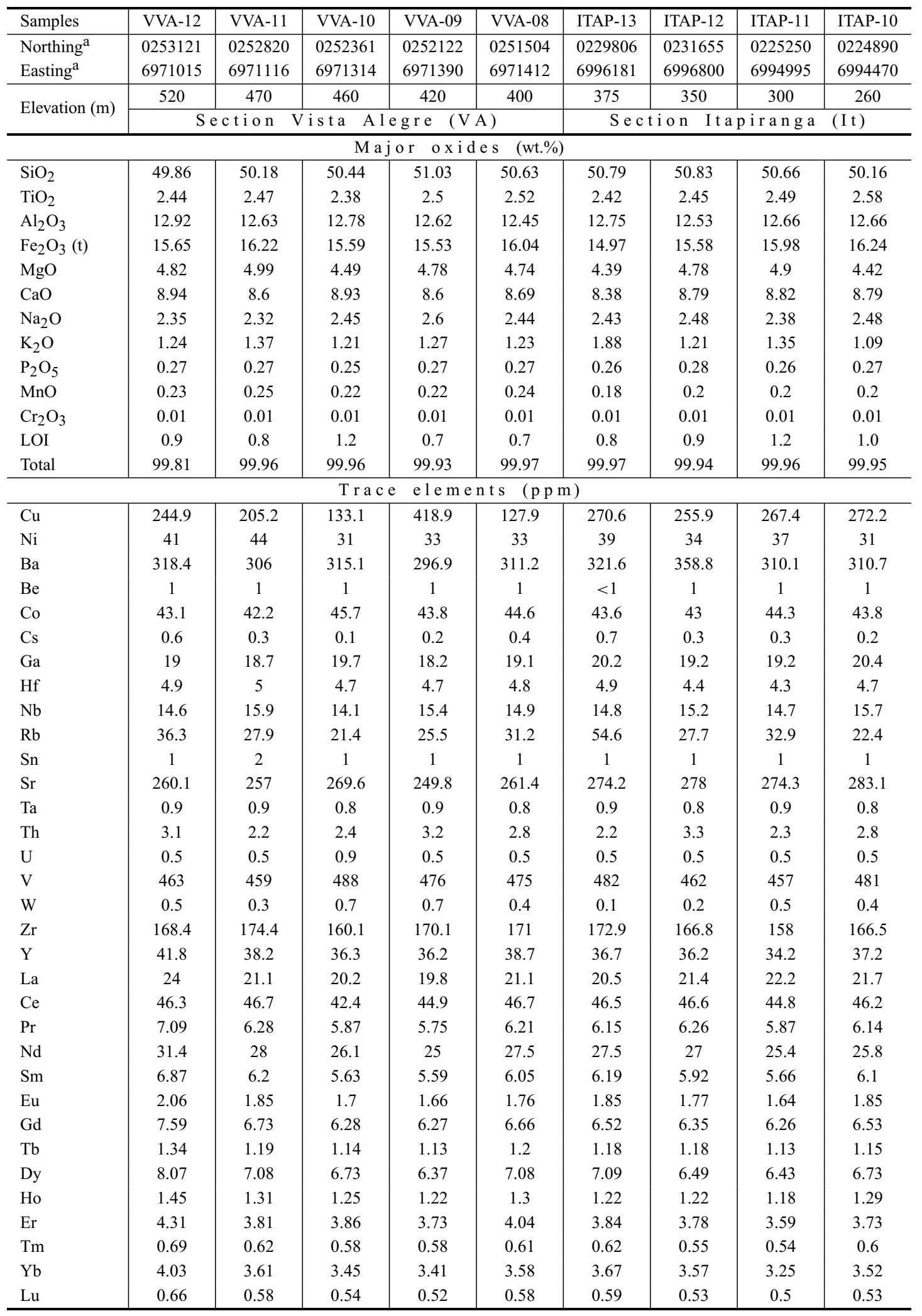


TABLE I (continuation)

\begin{tabular}{|c|c|c|c|c|c|c|c|}
\hline Samples & VSP-12 & VSP-11 & VSP-10 & VSP-09 & VSP-08 & VSP-07 & VSP-06 \\
\hline Northing $^{\mathrm{a}}$ & 0250950 & 0251071 & 0249537 & 0249290 & 0249188 & 0249080 & 0248570 \\
\hline Easting $^{\mathrm{a}}$ & 6974435 & 6975514 & 6974542 & 6974800 & 6974775 & 6974981 & 6975128 \\
\hline \multirow{2}{*}{ Elevation (m) } & 520 & 480 & 465 & 420 & 400 & 385 & 345 \\
\hline & \multicolumn{7}{|c|}{ Section $\quad$ São $\quad$ P a ulo $\quad$ (S P ) } \\
\hline \multicolumn{8}{|c|}{ Major oxides (wt.\%) } \\
\hline $\mathrm{SiO}_{2}$ & 49.58 & 50.83 & 51.18 & 49.79 & 50.83 & 50.55 & 49.71 \\
\hline $\mathrm{TiO}_{2}$ & 2.44 & 2.54 & 2.41 & 2.51 & 2.47 & 2.30 & 2.11 \\
\hline $\mathrm{Al}_{2} \mathrm{O}_{3}$ & 12.68 & 12.46 & 12.7 & 12.35 & 12.65 & 12.95 & 13.45 \\
\hline $\mathrm{Fe}_{2} \mathrm{O}_{3}(\mathrm{t})$ & 15.22 & 15.52 & 17.13 & 15.52 & 15.77 & 14.96 & 13.62 \\
\hline $\mathrm{MgO}$ & 4.74 & 4.74 & 4.66 & 4.64 & 4.59 & 5.35 & 5.94 \\
\hline $\mathrm{CaO}$ & 8.87 & 8.57 & 8.62 & 8.28 & 8.64 & 9.42 & 9.79 \\
\hline $\mathrm{Na}_{2} \mathrm{O}$ & 2.26 & 2.37 & 2.51 & 2.47 & 2.39 & 2.37 & 2.36 \\
\hline $\mathrm{K}_{2} \mathrm{O}$ & 1.17 & 1.29 & 1.29 & 1.35 & 1.37 & 0.75 & 1.11 \\
\hline $\mathrm{P}_{2} \mathrm{O}_{5}$ & 0.25 & 0.25 & 0.26 & 0.27 & 0.29 & 0.26 & 0.23 \\
\hline $\mathrm{MnO}$ & 0.2 & 0.22 & 0.21 & 0.22 & 0.23 & 0.23 & 0.21 \\
\hline $\mathrm{Cr}_{2} \mathrm{O}_{3}$ & 0.01 & 0.01 & 0.01 & 0.01 & 0.01 & 0.01 & 0.02 \\
\hline LOI & 1.8 & 1.1 & 0.6 & 0.7 & 0.7 & 0.8 & 1.4 \\
\hline Total & 99.79 & 99.92 & 99.98 & 99.83 & 99.95 & 99.96 & 99.96 \\
\hline \multicolumn{8}{|c|}{ Trace elements (ppm) } \\
\hline $\mathrm{Cu}$ & 238.6 & 274.6 & 107.7 & 131.6 & 139.4 & 257.8 & 200.9 \\
\hline $\mathrm{Ni}$ & 52 & 44 & 46 & 39 & 41 & 44 & 56 \\
\hline $\mathrm{Ba}$ & 286.1 & 314.3 & 328.2 & 337.2 & 310.6 & 296 & 300.9 \\
\hline $\mathrm{Be}$ & $<1$ & $<1$ & 1 & 1 & 1 & 1 & 1 \\
\hline Co & 42.5 & 43.3 & 43.4 & 45.1 & 43 & 46.4 & 46.2 \\
\hline Cs & 0.2 & 0.3 & 0.3 & 0.3 & 0.3 & 0.3 & 0.2 \\
\hline $\mathrm{Ga}$ & 18.7 & 18.6 & 19.6 & 19.2 & 19.8 & 18.3 & 18.7 \\
\hline Hf & 4.2 & 4.7 & 4.7 & 4.7 & 4.8 & 4.1 & 3.9 \\
\hline $\mathrm{Nb}$ & 13.5 & 14.2 & 14.8 & 14.3 & 14.9 & 14.3 & 12.6 \\
\hline $\mathrm{Rb}$ & 24 & 28.1 & 29.2 & 42.9 & 31.5 & 13 & 32 \\
\hline $\mathrm{Sn}$ & 1 & 1 & 1 & 2 & 1 & 1 & 1 \\
\hline $\mathrm{Sr}$ & 255.4 & 254.1 & 271.7 & 261.7 & 262.1 & 296.4 & 332.8 \\
\hline $\mathrm{Ta}$ & 0.8 & 0.8 & 0.8 & 0.9 & 0.9 & 1.3 & 0.7 \\
\hline Th & 2.5 & 2.6 & 2.5 & 2.4 & 2.9 & 2.1 & 2.2 \\
\hline $\mathrm{U}$ & 0.4 & 0.6 & 0.5 & 0.5 & 0.5 & 0.5 & 0.4 \\
\hline V & 443 & 459 & 487 & 462 & 479 & 458 & 420 \\
\hline W & 0.3 & 0.5 & 0.4 & 0.4 & 0.3 & 0.3 & 0.2 \\
\hline $\mathrm{Zr}$ & 157.4 & 164.9 & 171.8 & 168.5 & 172.3 & 149.6 & 134.6 \\
\hline $\mathrm{Y}$ & 35.6 & 36.6 & 37.9 & 37.7 & 37.8 & 34.2 & 30.7 \\
\hline $\mathrm{La}$ & 19.1 & 20.5 & 21.2 & 21.2 & 21.1 & 18.9 & 21.1 \\
\hline $\mathrm{Ce}$ & 42.2 & 44.3 & 45.4 & 45.6 & 46.4 & 42.2 & 41.6 \\
\hline $\operatorname{Pr}$ & 5.55 & 5.76 & 6.08 & 6.19 & 6.08 & 5.51 & 6.01 \\
\hline $\mathrm{Nd}$ & 24.9 & 26.5 & 27.1 & 27.5 & 26 & 24.2 & 25.8 \\
\hline $\mathrm{Sm}$ & 5.38 & 6.1 & 6.09 & 6.13 & 6.07 & 5.37 & 5.63 \\
\hline $\mathrm{Eu}$ & 1.67 & 1.71 & 1.77 & 1.8 & 1.8 & 1.68 & 1.74 \\
\hline $\mathrm{Gd}$ & 5.65 & 6.01 & 6.62 & 6.57 & 6.56 & 5.97 & 5.9 \\
\hline $\mathrm{Tb}$ & 1.1 & 1.14 & 1.16 & 1.2 & 1.18 & 1.06 & 1.04 \\
\hline Dy & 5.69 & 6.23 & 6.88 & 6.88 & 6.95 & 6.34 & 6.18 \\
\hline Но & 1.2 & 1.3 & 1.31 & 1.28 & 1.29 & 1.21 & 1.07 \\
\hline $\mathrm{Er}$ & 3.59 & 3.78 & 3.8 & 4.03 & 3.93 & 3.47 & 3.09 \\
\hline $\mathrm{Tm}$ & 0.5 & 0.55 & 0.63 & 0.62 & 0.6 & 0.55 & 0.48 \\
\hline $\mathrm{Yb}$ & 3.35 & 3.57 & 3.65 & 3.6 & 3.46 & 3.33 & 2.92 \\
\hline $\mathrm{Lu}$ & 0.48 & 0.51 & 0.59 & 0.57 & 0.54 & 0.52 & 0.45 \\
\hline
\end{tabular}

${ }^{\mathrm{a} C o ́ r r e g o ~ A l e g r e ~ D a t u m ~}$ 


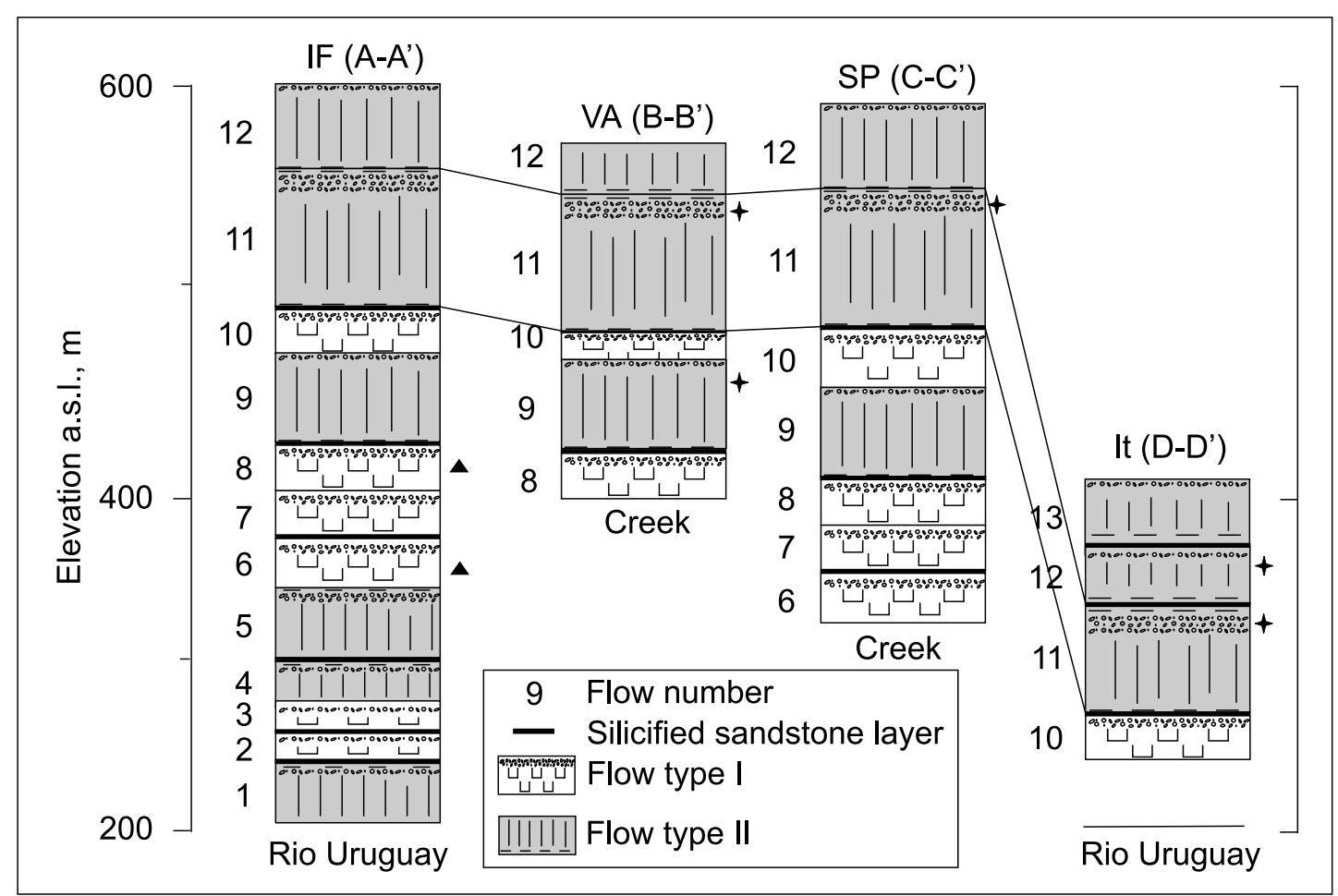

Fig. 3 - Correlation of four stratigraphic sections in the Vista Alegre region. Dark triangles indicate amethyst-bearing geode occurrence (after Gomes 1996) and dark stars the copper occurrences (this work). Nearly $200 \mathrm{~m}$ down-drop of Itapiranga section is indicated. IF $=$ Iraí-Frederico Westphalen section (A - A'), VA = Vista Alegre section (B - B'), SP = São Paulo section (C - C'), It = Itapiranga section (D - D').
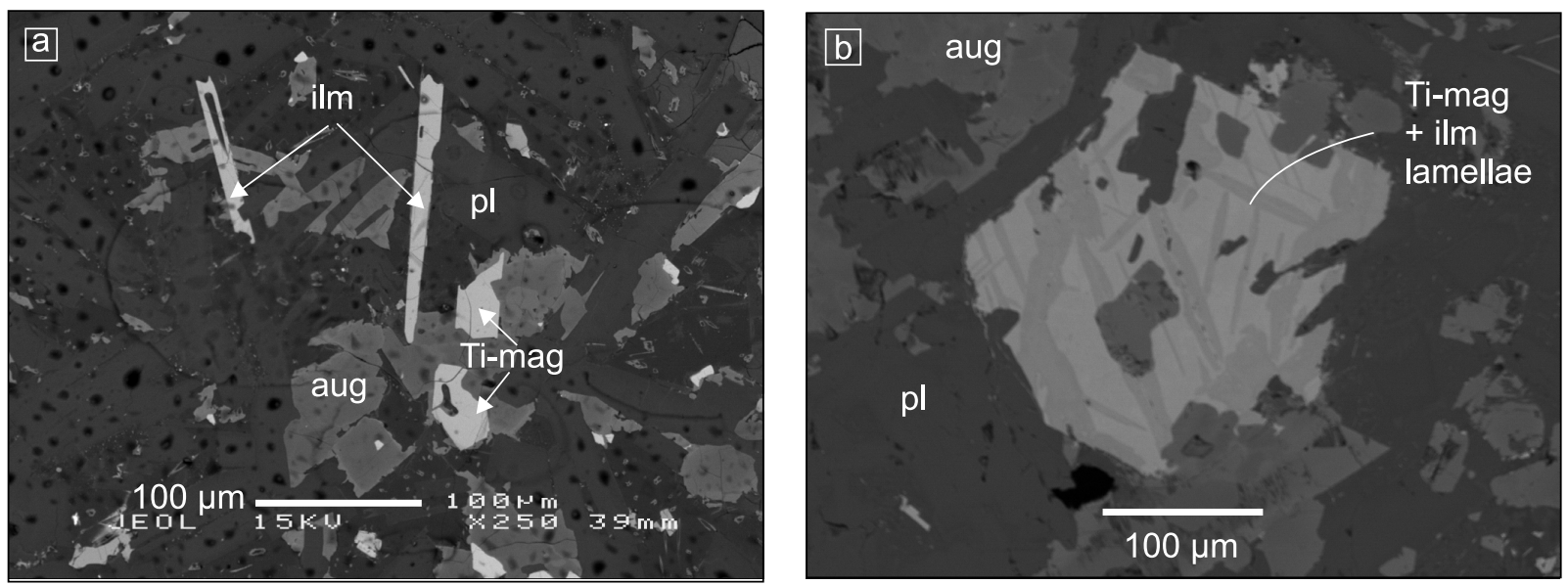

Fig. 4 - BSE images; (a) ilmenite and Ti-magnetite pair in flow 4; (b) ilmenite lamellae in Ti-magnetite grain from flow 11.

$\mathrm{Ti} / \mathrm{Zr}$ ratios are similar in all flows, but slightly higher in flows 1-5 $(\sim 85)$ than in flows 6-13 $(\sim 80)$. Based on these ratios and the $\mathrm{TiO}_{2}$ contents (Fig. 6), the flows are Pitanga-type at the base of the stratigraphic section (flows 1-5) and Paranapanema type in the upper portion (flows 6-13), based on criteria from Peate et al. (1992). This stratigraphy of magma types is reflected in variations in flow composition, including minor oxides $\left(\mathrm{TiO}_{2}\right.$ and $\mathrm{P}_{2} \mathrm{O}_{5}$ ), HFSE (e.g. Hf and $\mathrm{Zr}$ ) and LREE (e.g. La and $\mathrm{Ce}$ ), as seen on diagrams against $\mathrm{MgO}$ (Fig. 7). 


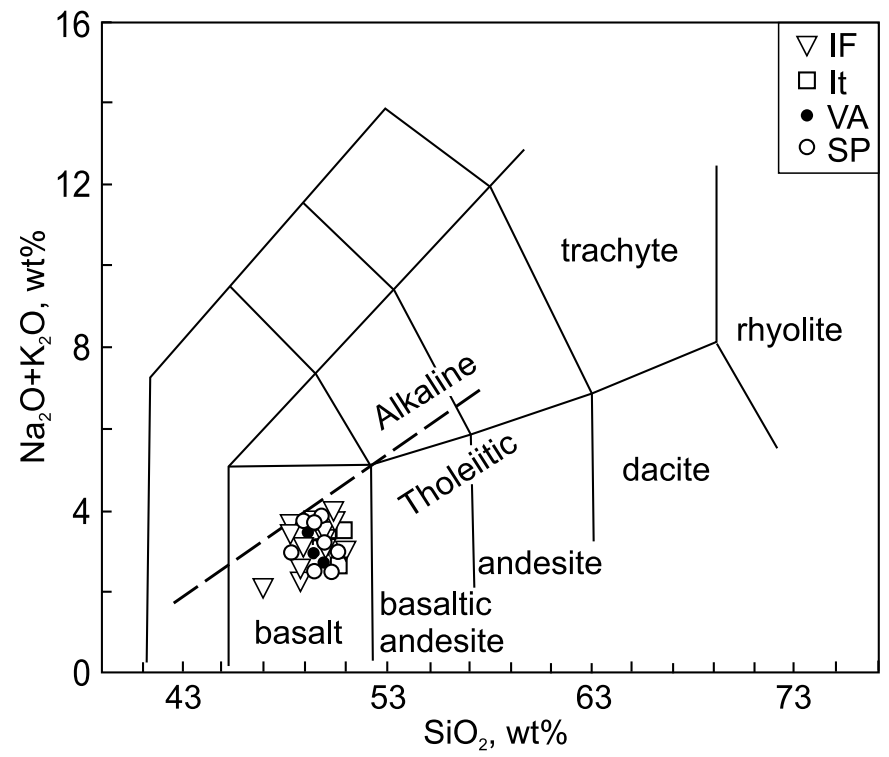

Fig. 5 - Total alkalis-silica (TAS) diagram (Le Bas et al. 1986) showing the geochemical characteristics of rocks from the Vista Alegre region. The bold, dashed line distinguishes tholeiitic from alkaline basalts (MacDonald and Katsura 1964).

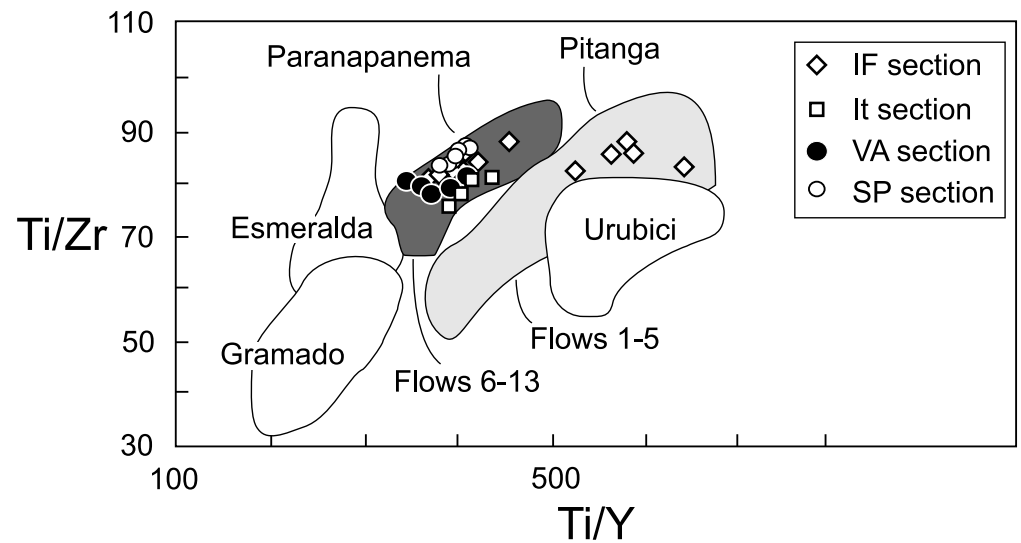

Fig. $6-\mathrm{Ti} / \mathrm{Y}$ versus $\mathrm{Ti} / \mathrm{Zr}$ diagram, showing the classification of samples from Vista Alegre region in the magma types of the Paraná volcanic province (after Peate 1997).

Flows are identified and correlated from small variations in $\mathrm{TiO}_{2}$ and $\mathrm{Zr}$ and from their relative stratigraphic position in each section. A significant observation (Fig. 8) is the parallel variation in chemistry $(\mathrm{MgO}$ $\times \mathrm{TiO}_{2}$ and $\mathrm{MgO} \times \mathrm{Zr}$ ) for all four stratigraphic sections analyzed. Flow 1 has 4.34 wt. \% MgO, flow 2 has $\sim 4$ wt.\%, the two subsequent flows have higher $\mathrm{MgO}$ $\sim 4.5$ wt.\% and then lower $\mathrm{MgO} \sim 4.3$ wt. \% in flow 5. Flows 6 and 7 in the IF and SP sections have the highest
$\mathrm{MgO}$ contents among the thirteen flows, with $\sim 5.8 \%$ in flow 6 and $\sim 5.3 \%$ in flow 7 . Flows 8 and 9 in IF, VA and SP sections show the smallest chemical differences, with $\mathrm{MgO}$ contents of $\sim 4.6 \%$ in flow 8 and $\sim 4.8 \%$ in flow 9, but are identified as distinct flows because of the presence of a thin $(\sim 0.5 \mathrm{~m})$ layer of silicified sandstone between the flows. Also, the structural types of flows 8 and 9 are markedly different (flow 8 is type I and flow 9 is type II; Gomes 1996). Flows 10-12 are 

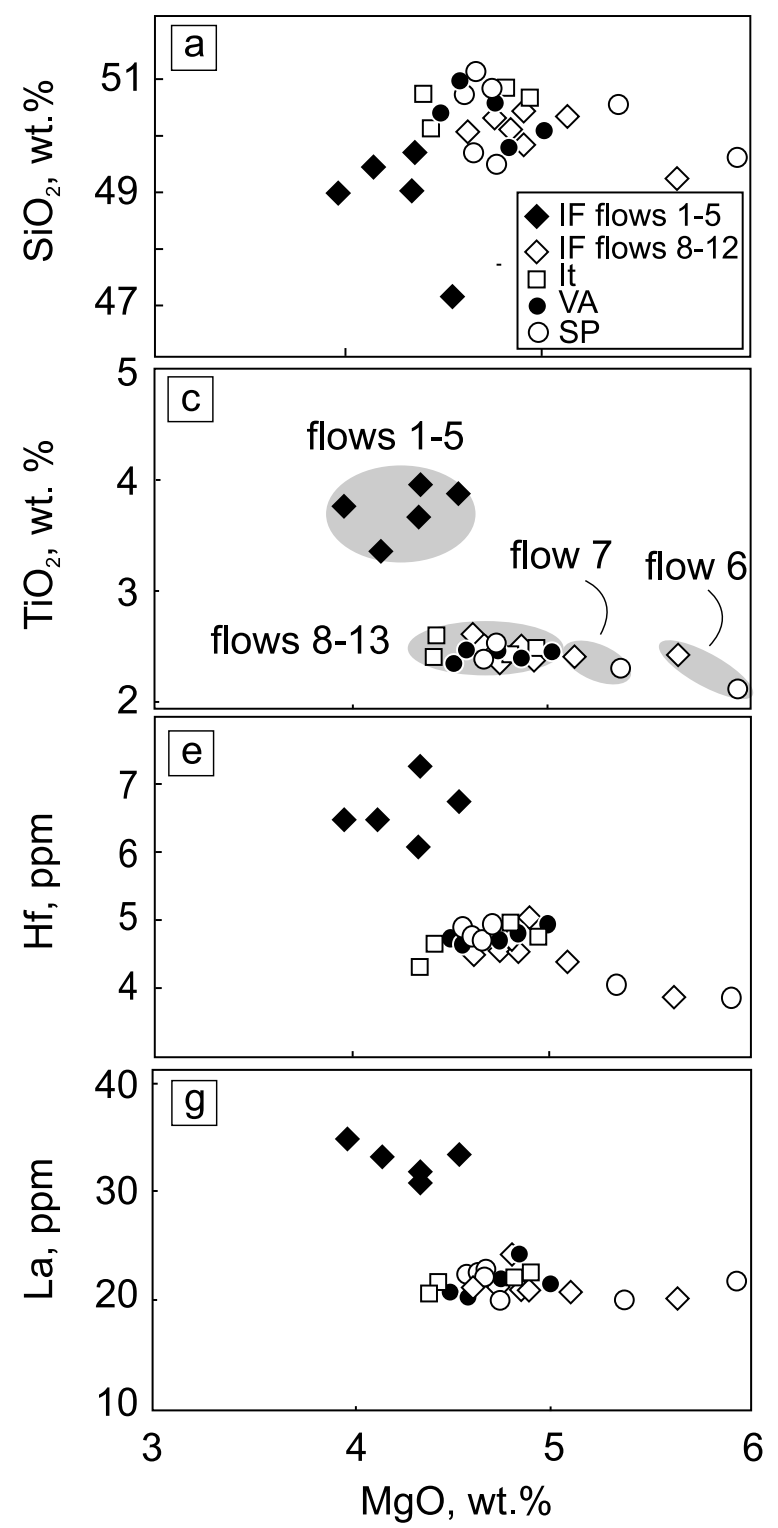

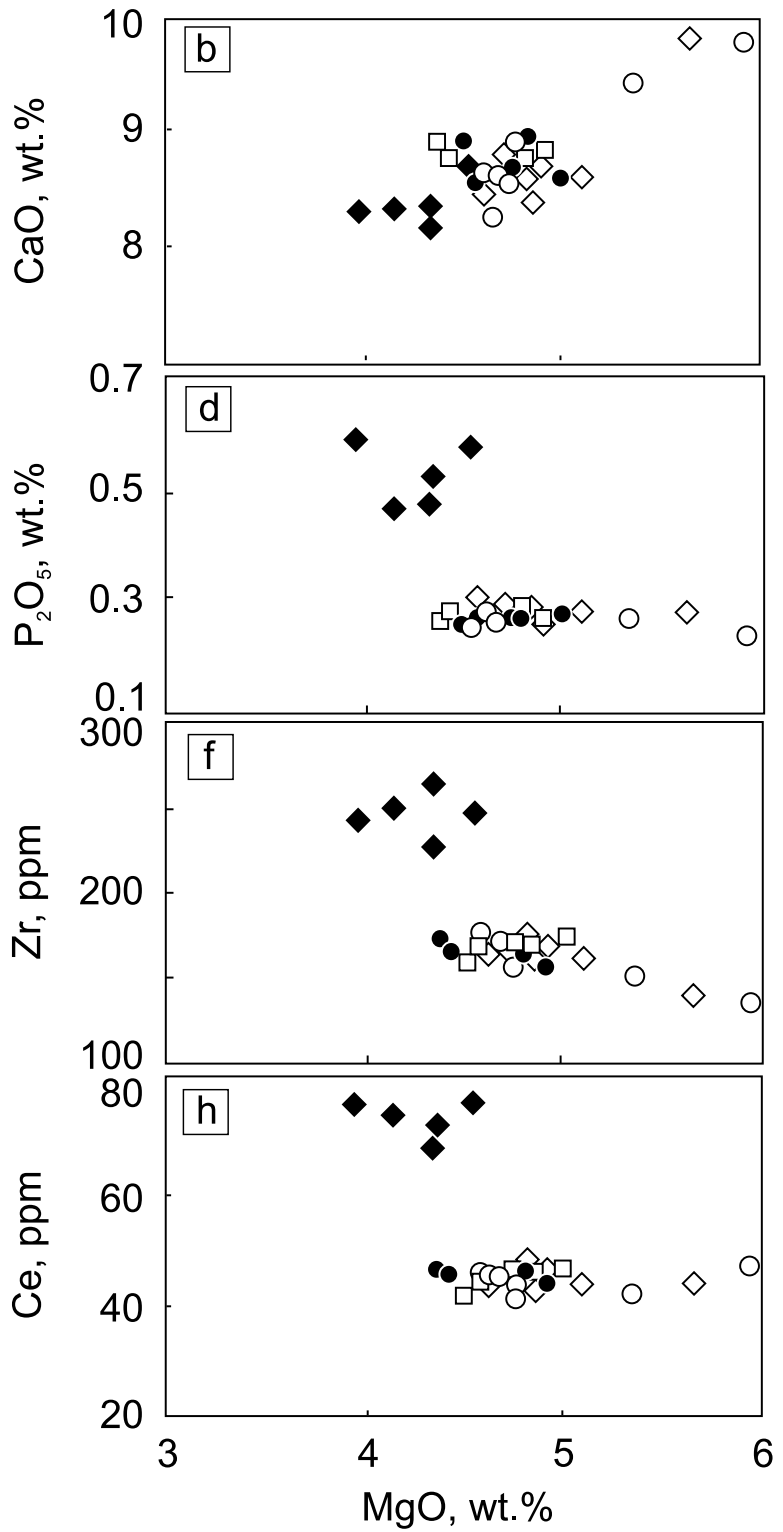

Fig. 7 - Variation diagrams of $\mathrm{MgO}$ versus major and trace elements in the flood basalts of the Vista Alegre region.

present in all four stratigraphic sections; $\mathrm{MgO}$ content increases from $\sim 4.5 \mathrm{wt} . \%$ in flow 10 to $\sim 5.0 \mathrm{wt} . \%$ in flow 11 , and then decreases to $\sim 4.7$ wt. $\%$ in flow 12 . $\mathrm{TiO}_{2}$ and $\mathrm{Zr}$ also vary consistently in the three flows. The uppermost flow 13 is uniquely present at the top of the Itapiranga section because it was presumably removed from the other sections by erosion.

The primitive mantle-normalized trace element content of the basalts shows similar patterns for both high-Ti and low-Ti magma types, with notable negative
Sr anomalies (Fig. 9a). All thirteen basalt flows are strongly enriched in light REE (LREE) relative to heavy REE (HREE), and display moderately sloping HREE on chondrite-normalized patterns (Fig. 9b). The two magma types share many characteristics in HFSE and REE pattern, but in detail the Pitanga and Paranapanema magmas show important differences in trace element abundance as exemplified in Figures $7 \mathrm{~g}-7 \mathrm{~h}$ and REE ratios as $(\mathrm{Sm} / \mathrm{Yb})_{\mathrm{N}}$ ratios of $\sim 3.0$ for Pitanga and $\sim 2.0$ for Paranapanema magma types. 

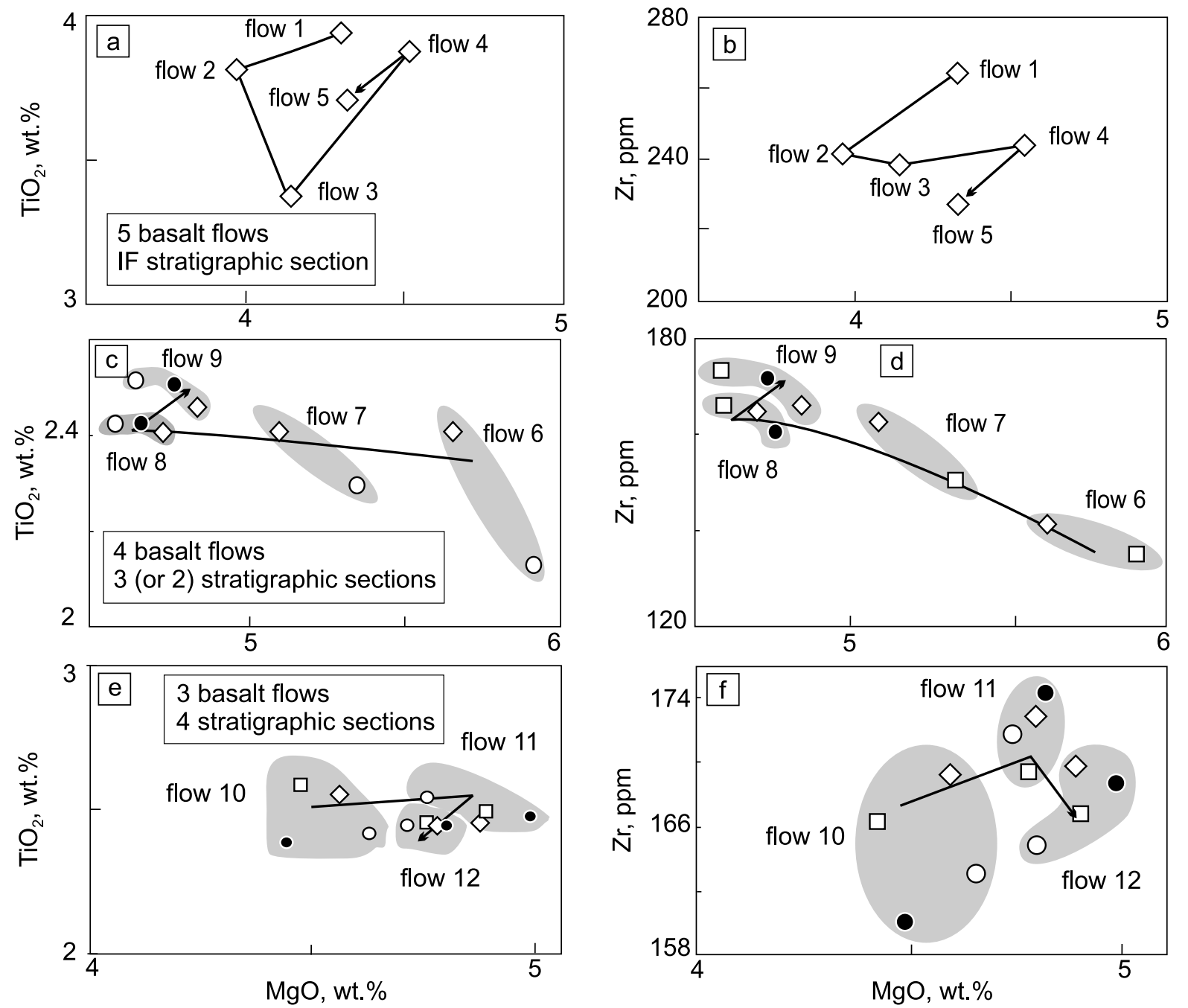

Fig. 8 - Variation diagrams of $\mathrm{MgO}$ versus $\mathrm{TiO}_{2}$ and $\mathrm{Zr}$ showing the correlation of flows 1-5 (a, b) in the IF (Iraí-Frederico Westphalen) section; flows 6-9 (c, d), with flows 6 and 7 in IF and SP (São Paulo) sections, while flows 8-9 include the VA (Vista Alegre) section; flows 10-12 are present in all four studied sections. Arrows indicate the stratigraphic sense of chemical variation of basalt flows. Symbols of stratigraphic sections are the same as Figure 6.
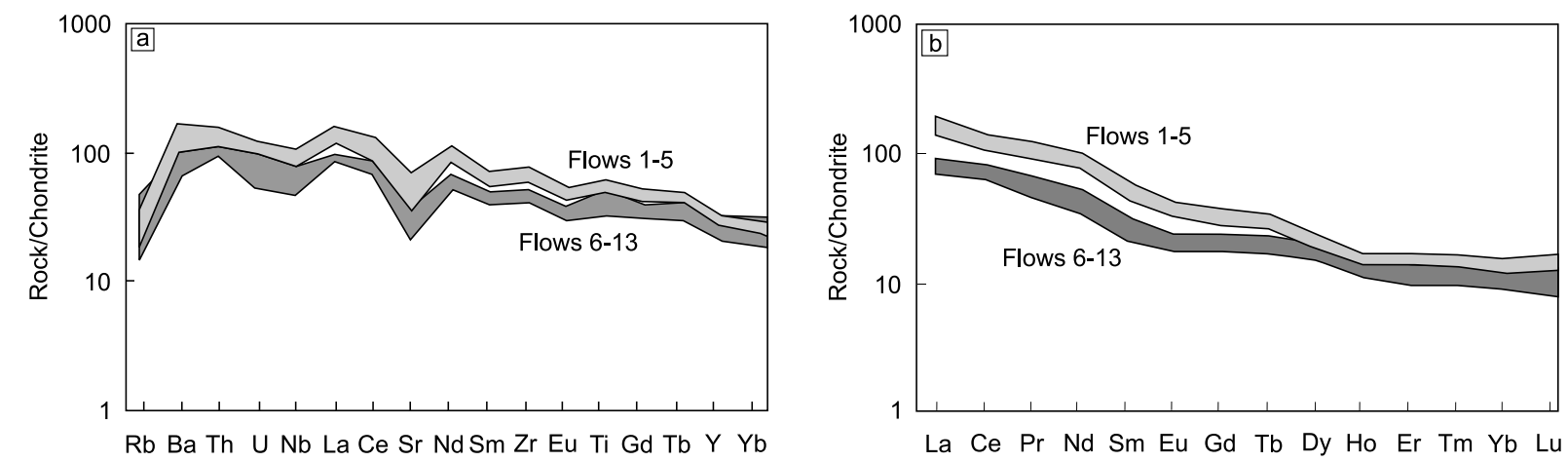

Fig. 9 - Basalt compositions from the Vista Alegre region. Primitive mantle-normalized trace element patterns in (a) and chondrite-normalized REE patterns in (b) of flows 1-5 (light gray) and flows 6-13 (dark gray) basalts. Normalization values are from Sun and McDonough (1989). 


\section{DISCUSSION}

\section{EFFECTS OF ALTERATION}

The Paraná basalts were affected by hydrothermal alteration of variable intensity following their eruption and burial. In the Vista Alegre region, the most intense alteration is related to amethyst or copper mineralization (Duarte et al. 2009, Hartmann 2008, Pinto et al. 2011). Hydrothermal alteration in basaltic rocks may have significantly modified the concentrations of oxides such as $\mathrm{Al}_{2} \mathrm{O}_{3}, \mathrm{Fe}_{2} \mathrm{O}_{3}(\mathrm{t})$ and $\mathrm{K}_{2} \mathrm{O}$, and some mobile trace elements such as $\mathrm{Rb}, \mathrm{Ba}, \mathrm{Sr}$ and $\mathrm{Cu}$ (Frantzon et al. 2008). On the other hand, $\mathrm{TiO}_{2}, \mathrm{REE}$ and HFSE have high valencies and electronegativities, small radii and strong chemical bonds, so they are nearly immobile during hydrothermal alteration (e.g. Wang et al. 2007). In Vista Alegre basalts, good linear correlations among $\mathrm{TiO}_{2}$, $\mathrm{P}_{2} \mathrm{O}_{5}$, LREE (e.g. La and Ce), HFSE (e.g. Hf and Zr) and $\mathrm{MgO}$ contents indicate that these elements remain immobile during the hydrothermal alteration that affected the rocks (e.g. Figs. 7c-7h). From these observations, we selected $\mathrm{TiO}_{2}$ and $\mathrm{Zr}$ to examine the flow-byflow stratigraphy of the Vista Alegre basalts.

\section{IMPLICATIONS OF CORRELATION}

Flow-by-flow correlation of basalts in the Vista Alegre region shows that the first five flows with elevations near 200-320 m above sea level occur only in the IF section starting in Iraí town on the left bank of Rio Uruguay. The uppermost eight flows are Paranapanema type. The upper flows in the IF stratigraphic section are also present in the SP and VA sections, and flow geometric position is nearly horizontal in the three sections.

The Itapiranga section has a similar elevation at the base compared to the IF section (220-320 m a.s.1.). The town of Itapiranga is on the right bank of Rio Uruguay and $40 \mathrm{~km}$ away from Iraí. It is remarkable that the lower three flows from Itapiranga (It section) correlate with the three uppermost flows from the IF, VA and SP sections (elevation 500-600 $\mathrm{m}$ a.s.1.). The correlation of flows 10, 11 and 12 indicates that the Itapiranga block was by down-faulted along the Rio Uruguai fault, so the right bank dropped approximately $200 \mathrm{~m}$ relative to the left bank (Fig. 3). The presence of the Rio Uruguay fault system affected the establishment of drainages patterns in the Vista Alegre region, because the rivers drain to NW along the left bank of Rio Uruguay and to SW along the right bank (Fig. 2). The uppermost flow 13 is only present in the Itapiranga section; this flow was probably removed in the other sections by erosion.

In the nearby Ametista do Sul mining district, the world-class amethyst deposits are in flows 6 and 8. Although additional deposits may be present in other flows, this identification of flows 6 and 8 in the region can lead to an expansion of the mining activity.

\section{GeOCHEMISTRY}

The stratigraphic distribution of magma types in the Vista Alegre region is the southern extension of the observations made on deep drill holes and outcrops by Mantovani et al. (1988) because Pitanga flows occur below Paranapanema flows. This overall sequence of magma eruption is present in most of the Paraná volcanic province. A supposed inversion of the stratigraphy (Turner et al. 1999) in Artigas (Uruguay) is a result of the presence of Paranapanema-type sills at depth in a borehole, as described by Hartmann et al. (2010).

This relation is confirmed and better understood from the observation of geochemical data of Pitanga and Paranapanema magma types. The differences in composition are influenced by melting and lead to considerations about the mantle-origin of the magma types. Pitanga magma type is considered derivative from an enriched mantle source (e.g. Peate 1997), but the origin of Paranapanema type may be from a more depleted mantle (e.g. Garland et al. 1996, Clark et al. 2007). The intermediate-Ti composition of Paranapanema magmas may reflect the transition between the high-Ti and low-Ti flows (Piccirillo et al. 1988).

The chemical data show that the negative Sr anomalies of both magma types may be related to extensive fractionation of plagioclase from high-Ti magmas, which is compatible with the presence of plagioclase phenocrysts in porphyritic or glomeroporphyritic flows. The lack of significant negative Eu anomaly in these lavas probably reflects either a high $\mathrm{Eu}^{+3} / \mathrm{Eu}^{+2}$ ratio in the magmas (Frey et al. 1991) or a lower distribution coefficient of $\mathrm{Eu}$ for An-rich plagioclase. 

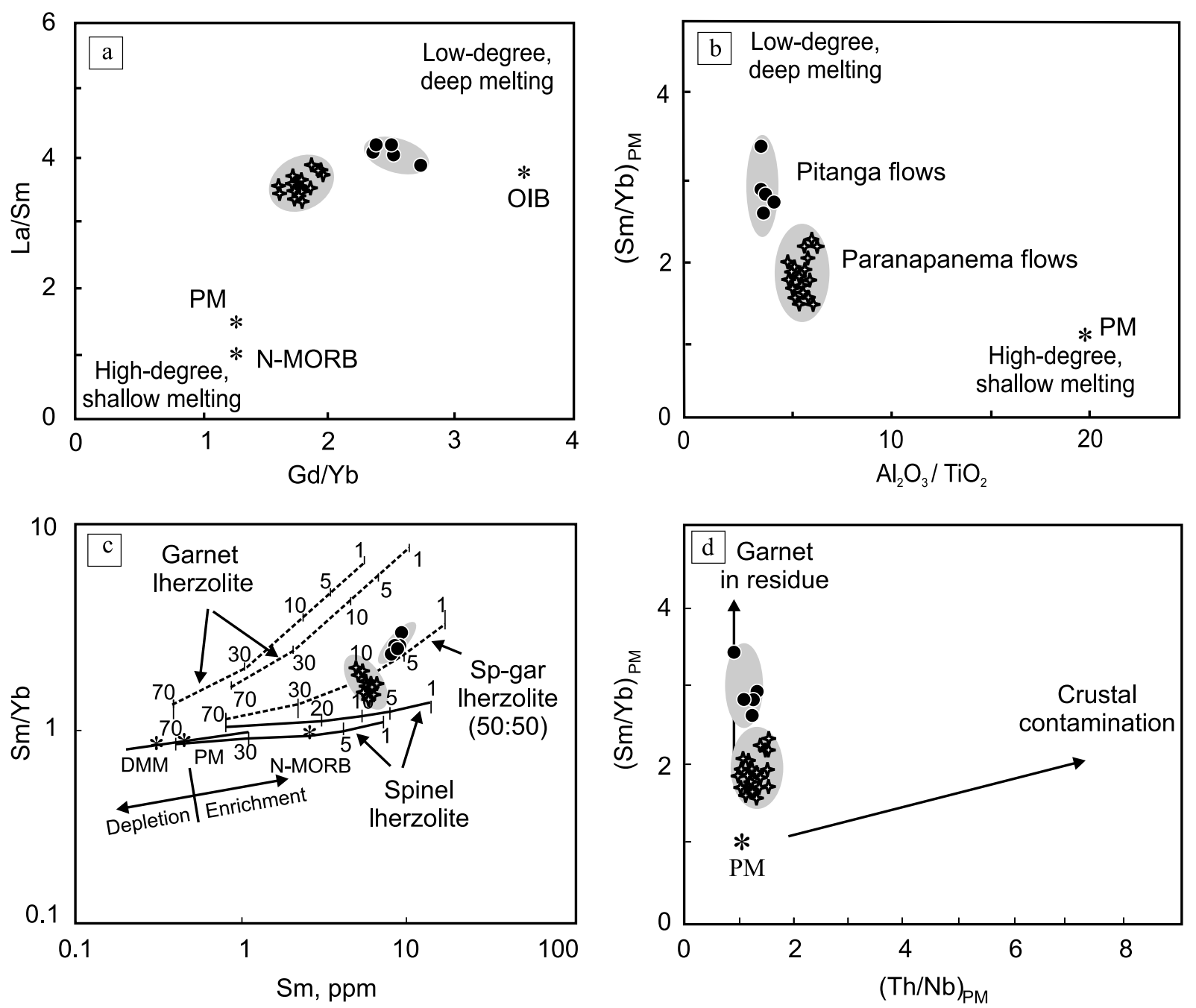

Fig. 10 - Plots of element and oxide ratios of the flood basalts from the Vista Alegre region indicating the nature and origin of the parental magmas and mantle process (a-b), plots of Sm versus $\mathrm{Sm} / \mathrm{Yb}$ showing melting curves (c); the referred melting curves are after Aldanmaz et al. 2000. Also, $(\mathrm{Th} / \mathrm{Nb})_{\mathrm{PM}}$ ratios (d) indicate the contribution of crustal contamination in the basalts; all diagrams based in Wang et al. (2007). Primitive mantle (PM) and N-MORB compositions are from Sun and McDonough (1989). Sp = Spinel; gar = garnet.

The rocks have chondrite-normalized REE patterns enriched in LREE and moderately sloping in HREE patterns, with relatively high $(\mathrm{Gd} / \mathrm{Yb})_{\mathrm{PM}}$ ratios (1.8 to 3.0) (Fig. 10a) and $\mathrm{Tb} / \mathrm{Yb}(\sim 1.5$ to $\sim 2.4$ ). This indicates the presence of residual garnet during partial melting (e.g. Green 1994), which is a feature of melting at greater depths.

Based in Aldanmaz et al. (2000), we plotted Sm versus $\mathrm{Sm} / \mathrm{Yb}$ to model the source characteristics in terms of mineralogy, because $\mathrm{Yb}$ is compatible with garnet, but not with clinopyroxene (Wang et al. 2007). The basalts of Pitanga magma type (flows 1-5) with higher $\mathrm{Sm} / \mathrm{Yb}$ plot between the melting trajectories for garnet and garnet + spinel-lherzolite, indicating that the magma was derived from a garnet + spinel-bearing mantle with more garnet (80-400 km depth) than spinel (50$80 \mathrm{~km}$ depth), suggest the formation of the Pitanga magma type at a depth higher than $100 \mathrm{~km}$ (after Wyllie 1981) and in agreement with the estimate of Garland et al. (1996). The Paranapanema basalts (flows 6-13) plot between garnet + spinel-lherzolite and spinel lherzolite, indicating that this magma was derived from a source similar to the Pitanga basalts, but with higher spinel content and at a shallower depth. 
The relatively low $\mathrm{Al}_{2} \mathrm{O}_{3} / \mathrm{TiO}_{2}$ ratios (Pitanga 3.23.7 and Paranapanema 4.9-5.4) and high $(\mathrm{Sm} / \mathrm{Yb})_{\mathrm{PM}}$ ratios (Pitanga $\sim 3$ and Paranapanema $\sim 2$ ) indicate lower degrees of partial melting of a relatively deeper mantle source for Pitanga basalts (Fig. 10b). The degree of partial melting, following the parameters of Aldanmaz (2000) and Wang et al. (2007), was probably less than $6 \%$ for the Pitanga and $\sim 10 \%$ for the Paranapanema parental magmas on the basis of $\mathrm{Sm}$ versus $\mathrm{Sm} / \mathrm{Yb}$ ratios (Fig. 10c).

The ratios of $(\mathrm{Th} / \mathrm{Nb})_{\mathrm{PM}}$ and $(\mathrm{Sm} / \mathrm{Yb})_{\mathrm{PM}}$ (Fig. 10d) indicate that the Paranapanema basalts originated from magma with less garnet in the residue than the Pitanga ones. Integrated with $(\mathrm{Nb} / \mathrm{La})_{\mathrm{PM}}$ ratios $(\sim 0.75$ for flows $1-5$ and 0.70 for upper flows), this suggests that crustal contamination was not significant.

The values of $(\mathrm{Nb} / \mathrm{La})_{\mathrm{PM}}$ ratios are lower than in South Atlantic MORB, asthenospheric and Tristan da Cunha plume magmas (respectively 0.96 and 1.34; cf. Garland et al. 1996), which suggests the melting of an enriched lithospheric mantle source (e.g. Peate et al. 1999).

\section{CONCLUSIONS}

The careful field control of the analyzed samples, reinforced by the high quality of the analyses, leads to some significant conclusions.

- Flow-by-flow stratigraphy is established for thirteen basalt flows in the Vista Alegre region.

- The five basal flows are Pitanga type and the eight upper flows are Paranapanema type, all high-Ti type.

- The stratigraphy of flows indicates that the Itapiranga block on the right bank of Rio Uruguay was down-faulted approximately $200 \mathrm{~m}$ with respect to the Frederico Westphalen block.

- The stratigraphy of the region accompanies the results from boreholes because Pitanga magma type was erupted prior to the Paranapanema magma type.

- Geochemistry indicates that the Pitanga basalts formed at $>100 \mathrm{~km}$ depth during the initial mantle upwelling by low degree $(\sim 6 \%)$ partial melting of enriched lithospheric mantle, while the Paranapanema basalts were formed in shallower depth with increased degree of partial melting, without evidence of crustal contamination.

- The stratigraphic correlation here established is useful for the identification of flows with amethyst or copper mineralization, because the Vista Alegre region constitutes a potential mining district.

\section{ACKNOWLEDGMENTS}

Support was given by Conselho Nacional do Desenvolvimento Científico e Tecnológico (CNPq), Fundação de Amparo à Pesquisa do Estado do Rio Grande do Sul (FAPERGS), Companhia de Pesquisa de Recursos Minerais (CPRM) and COOGAMAI (miners cooperative). A main support for the investigation was the project of excellence: "Minerais Estratégicos do Sul do Brasil", supported by FAPERGS/CNPq and coordinated by LAH. Wilson Wildner (Geological Survey of Brazil) is acknowledged for his expertise on Serra Geral Group basalts.

\section{RESUMO}

A caracterização geoquímica de treze derrames do Grupo Serra Geral na região de Vista Alegre (RS e SC), sul do Brasil, exibe uma composição basáltica homogênea próxima a $50 \%$ de $\mathrm{SiO}_{2}$. Os cinco derrames basais são classificados quimicamente como tipo Pitanga (alto $\mathrm{Ti} / \mathrm{Y} \sim 600$ e $\mathrm{TiO}_{2}>3$ em peso percentual), os demais oito derrames possuem médio $\mathrm{Ti} / \mathrm{Y}$ $\sim 400$ com $\mathrm{TiO}_{2} \sim 2.5$ em peso percentual, sendo classificados como magma tipo Paranapanema. Cada derrame pode ser identificado através de sua composição química e correlacionado, com variação paralela entre os perfis estudados. A correlação derrame a derrame nos quatro perfis demonstra uma posição horizontal em três perfis e um rejeito vertical de aproximadamente $200 \mathrm{~m}$ do bloco Itapiranga em relação ao bloco Frederico Westphalen. A presença de jazidas de ametista em geodos e a sistemática ocorrência de cobre nativo nos basaltos da região tornam a correlação de grande significado geológico e econômico.

Palavras-chave: Correlação geoquímica, basalto, estratigrafia, Grupo Serra Geral, Vista Alegre.

\section{REFERENCES}

Aldanmaz E, Pearce JA, Thirlwall MF and MitCHEL JG. 2000. Petrogenetic evolution of late Cenozoic, post-collision volcanism in western Anatolia, Turkey. J Volcanol Geotherm Res 102: 67-95. 
Beane Je, Turner CA, Hooper PR, Subbarao KV AND WALSH JN. 1986. Stratigraphy, composition and form of the Deccan Basalts, Western Ghats, India. Bull Volcanol 48: 61-83.

Bellieni G, Comin-Chiaramonti P, Marques LS, Melfi AJ, Piccirillo EM, Nardy AJR, Stolfa D AND Roisenberg A. 1984. High- and low-Ti flood basalts from the Paraná plateau (Brazil): petrology and geochemical aspects bearing on their mantle origin. Neues Fahrbuch Min Abh 150: 272-306.

Clark RJ, Peate DW and Rogers NW. 2007. Petrogenesis of high-Ti/Y magma types of the western Paraná flood basalt Province. Geol Soc Am Abstracts with Programs 39(3): 11 .

Cox KG AND Hawkesworth CJ. 1985. Geochemical stratigraphy of the Deccan traps at Mahabaleshwar, Western Ghats, India, with implications for open system magmatic processes. J Petrol 26: 355-377.

Duarte LC, Hartmann LA, Vasconcelos MAZ, MeDEIROS JTN AND THEYE T. 2009. Epigenetic formation of amethyst-bearing geodes from Los Catalanes gemological district, Artigas, Uruguay, southern Paraná MagmaticProvince. J Volcanol Geotherm Res 184: 427-436.

Frantzon H, ZiERENBERG R AND SCHIFFMAN P. 2008. Chemical transport in geothermal systems in Iceland: Evidence from hydrotermal alteration. J Volcanol Geotherm Res 173: 217-229.

Frey FA, Garcia mo, Wise WS, Kennedy A, GurRIET P AND Albarede F. 1991. The evolution of Mauna Kea volcano, Hawaii: petrogenesis of tholeiitic and alkali basalts. J Geophys Res 96: 14347-14375.

Garland F, TURner SP AND HaWkesworth CJ. 1996. Shifts in the source of the Paraná basalts through time. Lithos 37: 223-243.

Gomes MEB. 1996. Mecanismos de resfriamento, estruturação e processos pós-magmáticos em basaltos da Bacia do Paraná - região de Frederico Westphalen (RS) - Brasil. PhD Thesis, Instituto de Geociências, Universidade Federal do Rio Grande do Sul, Porto Alegre, Brasil, 219 p.

GREEN TH. 1994. Experimental studies of trace-element partitioning applicable to igneous petrogenesis - Sedona 16 years later. Chem Geol 117: 1-36.

HARTMAnN LA. 2008. Amethyst geodes formed from hot water in dinossaur times. Gráfica da Universidade Federal do Rio Grande do Sul, Porto Alegre, Brasil, Porto Alegre, $57 \mathrm{p}$.

Hartmann LA, Wildner W, Duarte LC, Duarte SK, Pertille J, Arena KR, Martins LC and Dias
NL. 2010. Geochemical and scintillometric characterization and correlation of amethyst geode-bearing Paraná lavas from the Quaraí and Los Catalanes districts, Brazil and Uruguay. Geol Mag 147: 954-970.

Le Bas MJ, Le Maitre RW, Streckeisen A, Zanettin B And Iugs Sub Commission on the SystematiC OF IGNEOUS Rocks. 1986. A chemical classification of volcanic rocks based on the total alkali-silica diagram. J Petrol 27(3): 745-750.

MacDonald GA And Katsura T. 1964. Chemical composition of Hawaiian lavas. J Petrol 5: 82-133.

Mantovani MSM, Peate DW and Hawkesworth CJ. 1988. Geochemical stratigraphy of Paraná continental flood basalts: A contribution from borehole samples. In: Piccirillo EM And Melfi AJ (Orgs), The Mesozoic flood volcanism from Paraná Basin (Brazil): Petrogenetic and geophysical aspects. Rev Bras Geoc 18(2): 212-221.

Peate DW. 1997. The Paraná-Etendeka Province. In: MAHONEY JJ AND COFFIN MR (Eds), Large Igneous Provinces: Continental, Oceanic, and Planetary Flood Volcanism. Am Geophysical Union Monograph 100, Washington DC, USA, p. 217-245.

Peate DW, Hawkesworth CJ, Mantovani MSM, Rogers NW AND TURner SP. 1999. Petrogenesis and Stratigraphy of the High-Ti/Y Urubici Magma Type in the Paraná Flood Basalt Province and Implications for the Nature of "Dupal" - Type Mantle in the South Atlantic Region. J Petrol 40: 451-473.

PEATE DW, HaWkesworth CJ AND Mantovani MSM. 1992. Chemical stratigraphy of the Paraná lavas (South America): classification of magma types and their spatial distribution. Bull Volcanol 55: 119-139.

Piccirillo EM, Melfi AJ, Comin-Chiaramonti P, Bellieni G, ERnesto M, Marques LS, Nardy AJR, Pacca IG, Roisenberg A And Stolfa D. 1988. Continental flood volcanism from the Paraná basin (Brazil). In: MACDougall JD (Ed), Continental Flood Basalts. Kluwer Acad Publ, p. 195-238.

Pinto VM, Hartmann LA And Wildner W. 2011. Epigenetic hydrothermal origin of native copper and supergene enrichment in the Vista Alegre district, Paraná basaltic province, southernmost Brazil, Int Geol Ver 53: 1163-1179.

Sun SS AND MCDonough WF. 1989. Chemical and isotopic systematics of oceanic basalts: implications for mantle composition and process. In: SAUNDERS AD AND Norry MJ (Eds), Magmatism in the Ocean Basins. Geol Soc Spec Publ 42: 313-345. 
SWANSON DA, Wright TL, HoOper PR AND BENTLEy RD. 1979. Revisions in stratigraphic nomenclature of the Columbia River Basalt Group. In: US Geol Surv Bull 1457-G, p. G1-G59.

Szubert EC, Grazia CA And Shintaku I. 1979. Projeto Cobre em Itapiranga, CPRM-Serviço Geológico do Brasil, Porto Alegre, RS, 474 p.

Turner SP, Peate DW, Hawkesworth CJ And ManTOVANI MSM. 1999. Chemical stratigraphy of the Paraná basalt succession in western Uruguay: further evidence for the diachronous nature of the Paraná magma types. J Geodyn 28: 459-469.

Wang CY, Zhou M-F And Qi L. 2007. Permian flood basalts and mafic intrusions in the Jinping (SW China)Song Da (northern Vietnam) district: Mantle sources, crustal contamination and sulfide segregation. Chem Geol 243: $317-343$.
WILDNER W, HARTMANN LA AND LOPES RC. (in press). A proposed stratigraphy for the Serra Geral Group in the Paraná Basin. In: Milani EJ AND Chemale JR F (Eds), Correlation Brazil-Africa. Gramado, Petrobras.

WYLlie PJ. 1981. Plate tectonics and magma genesis. Geol Rundsch 70: 128-153.

Xu YG, Chung SL, Jahn BM and Wu GY. 2001. Petrologic and geochemical constraints on the petrogenesis of Permian-Triassic Emeishan flood basalts in southwestern China. Lithos 58: 145-168. 